\title{
HUBUNGAN HYGIENE DAN SANITASI DENGAN KONTAMINASI Escherichia coli PADA JAJANAN BERSAUS DI PENDIDIKAN SEKOLAH DASAR SE-WILAYAH DESA WATUAGUNG KECAMATAN TAMBAK KABUPATEN BANYUMAS TAHUN 2016
}

\author{
Ristoyo $^{1)}$, Budi Triyantoro'), Zaeni Budiono ${ }^{3)}$ \\ Jurusan Kesehatan Lingkungan, Politeknik Kesehatan Kemenkes Semarang, \\ Jl.Raya Baturaden KM 12 Purwokerto, Indonesia
}

\begin{abstract}
Abstrak
Makanan jajanan memegang peranan yang cukup penting dalam memberikan asupan energi gizi bagi anakanak usia sekolah. Di lingkungan sekitar sekolah banyak sekali dijumpai makanan jajanan yang disediakan oleh pedagang kaki lima dan umumnya jajanan bersaus rutin dikonsumsi oleh sebagian usia sekolah. Data siswa sekolah dasar Desa Watuagung yang berobat ke Puskesmas I Tambak tahun 2015 sebanyak 48 siswa. Tujuan dari penelitian ini adalah untuk Mengetahui hubungan hygiene dan sanitasi dengan kontaminasi Escherichia coli pada Jajanan Bersaus di Pendidikan Sekolah Dasar se-wilayah Desa Watuagung, Kecamatan Tambak, Kabupaten Banyumas Tahun 2016. Metode penelitian yang digunakan adalah analitik dengan pendekatan cross sectional. Jumlah sampel sebanyak 30 penjual makanan bersaus yang ada di Pendidikan Sekolah Dasar se-wilayah Desa Watuagung, Kecamatan Tambak, Kabupaten Banyumas Tahun 2016 menggunakan teknik total sampling. Hasil penelitian menyatakan bahwa Makanan jajanan bersaus yang berasal dari 30 pedagang, yang terjadi kontaminasi E. Coli sebanyak 15 makanan (50,0\%) dan yang tidak terjadi kontaminasi sebanyak 15 makanan (50,0). Perilaku hygiene pada kategori kurang baik sebanyak 16 pedagang (53,3\%) dan yang pada kategori baik sebanyak 14 pedagang (46,7\%). Sanitasi tempat berjualan perilaku hygiene pada kategori kurang baik sebanyak 11 pedagang (36,7\%) dan yang pada kategori baik sebanyak 19 pedagang (63,3\%). Penelitian ini disimpulkan ada hubungan perilaku hygiene sanitasi dengan kontaminasi Escherichia coli pada jajanan bersaus di Pendidikan Sekolah Dasar se-wilayah Desa Watuagung, Kecamatan Tambak, Kabupaten Banyumas Tahun 2016 ( $p$ value = 0,003). Ada hubungan sanitasi tempat berjualan dan alat dengan kontaminasi Escherichia coli pada jajanan bersaus di Sekolah Dasar Desa Watuagung, Kecamatan Tambak, Kabupaten Banyumas Tahun 2016 ( $p$ value = 0,023). Disarankan penelitian ini perlu dikembangkan lebih lanjut dengan meneliti faktor lain yang dapat mempengaruhi kontaminasi E. coli dengan meneliti praktek pengolahan makanan di rumah pedagang.
\end{abstract}

Kata Kunci : Hygiene, Sanitasi, Escherichia coli

\begin{abstract}
Snacks is being important to give suplay energy nutrition for a child of school. In territory of school we know that seller is sell snacks with sauce that will be eat child of school. The data of studet who check up to the health center of Tambak I on 2015 amount 48 students. The purpose of this research is to know the correlati hygiene and sanitation with contamination escherichia coli in snacks with sauce at all primary school on watuagung territory, Tambak, Banyumas on 2016. The design of this research is a analytic with cross sectional approach. The population in this study were all seller of the street food in the primary school on watuagung territory, Tambak, Banyumas with a number of sampels were taken by 30 food vendors in the village of primary school on watuagung, Tambak, Banyumas 2016 using total sampling technique. The study states that the snacks food from 30 vendors, E.Coli contamination that occured as many as 15 meals (50.0\%) and that no contamination as much as 15 meals (50.0\%), hygiene behaviour in the unfavorable category by 16 merchants (53.3 \%)and in both categories a total of 14 merchant (46.7\%), sanitary place to sell and tool hygiene behaviour in the unfavorable category as many as 11 traders (36.7\%) and were in good category were 19 traders (63.3\%). The conclusion $f$ this research is : there is a correlati of behavior hygiene and sanitation with contamination escherichia coli in snacks with sauce at all primary scholl on watuagung territory, Tambak, Banyumas on 2016 ( $p$ value $=0,003$ ). There is sanitary place and tools with escherichia coli contamination in snacks with sauce at all primary scholl on watuagung territory, Tambak, banyumas on 2016 ( $p$ value $=0,023$ ). The research should be developed further to examine other factors that may effect $E$. coli contamination the practice of food processing at home adress.
\end{abstract}

Keywords : : Hygiene, Sanitation, Escherichia coli

\section{PENDAHULUAN}

Makanan merupakan salah satu kebutuhan pokok manusia untuk dapat melangsungkan kehidupan

1) Email : ristoyohs@gmail.com

2) Email : mutshabira@yahoo.co.id

3) Email : pakzaeni@gmail.com selain kebutuhan sandang dan perumahan. Makanan selain mengandung nilai gizi juga merupakan media untuk dapat berkembang biaknya mikroba atau 
kuman terutama makanan yang mudah membusuk yaitu makanan yang banyak mengandung kadar air serta nilai protein yang tinggi. Kemungkinan lain masuknya atau beradanya bahan-bahan berbahaya seperti bahan kimia, risidu pestisida serta bahan lainnya antara lain debu, tanah, rambut manusia dapat berpengaruh buruk terhadap kesehatan manusia (Depkes RI, 2010)

Penjual makanan sebagai salah satu jenis pelayanan umum yang mengolah dan menyediakan, memiliki potensi yang cukup besar untuk menimbulkan gangguan kesehatan atau penyakit bawaan makanan yang dihasilkannya. Dengan demikian kualitas makanan yang dihasilkan, disajikan dan dijual oleh penjual makanan harus memenuhi syarat kesehatan seperti faktor lokasi dan bangunan, fasilitas sanitasi, peralatan, pengolahan makanan yang baik dan penjamah makanannya sendiri (Depkes RI, 2010).

Higiene sanitasi merupakan hal yang penting dalam menentukan kualitas makanan dimana Escherichia coli sebagai salah satu indikator terjadinya pencemaran makanan yang dapat menyebabkan penyakit akibat makanan (food borne diseases). Bakteri-bakteri indikator sanitasi umumnya bakteri yang terdapat dan hidup sebagai flora normal pada usus manusia. Bakteri E. coli dapat menimbulkan gangguan kesehatan seperti penyakit diare apabila masuk ke saluran pencernaan, baik melalui minuman maupun makanan. Peraturan Menteri Kesehatan RI nomor 1098/Menkes/SK/VII/2003 angka kuman E. coli pada makanan harus 0/gram sampel makanan dan pada minuman angka kuman E. coli harus 0/100 ml sampel minuman. Lebih dari 90\% anak usia SD kecuali Taman Kanak-kanak (TK) tidak membawa bekal makanan dari rumah, sebagai gantinya mereka dibekali uang untuk membeli makanan jajanan di sekolah dasar (Depkes RI; 2006). Anak usia SD (6-12 tahun) memiliki kebiasaan jajan dan sudah dapat memilih serta menentukan makanan apa yang disukai dan tidak. Untuk hal tersebut makanan jajanan di SD selain faktor gizi, perlu juga diperhatikan faktor sanitasi dan higienisnya (Judarwanto, 2010).

Badan Pengawasan Obat dan Makanan (BPOM) menyatakan bahwa $45 \%$ produk pangan olahan di lingkungan SD tercemar bahan berbahaya mulai dari fisik, kimiawi, maupun mikrobiologi. Wajar saja jika SD dan kampus merupakan tempat yang paling sering menyebabkan kasus keracunan makanan setelah di rumah tangga (BPOM, 2010). Penelitian Kurniadi, dkk., (2013) menyimpulkan bahwa penyajian makanan, fasilitas sanitasi dan tenaga penjamah memiliki hubungan yang signifikan dengan kontaminasi E. coli pada makanan jajanan di lingkungan kantin sekolah dasar wilayah Kecamatan Bangkinang, Kabupaten Kampar. Faktor yang paling dominan terhadap kontaminasi E. coli pada makanan jajanan di lingkungan kantin sekolah dasar wilayah
Kecamatan Bangkinang adalah variabel penyajian makanan.

Jenis makanan yang banyak dijual di sekolah dasar yang mudah terkontaminasi bakteri, yaitu ; cakue, cireng, cilok, sosis goreng, dan mi goreng. Faktor yang diperkirakan mempengaruhi kandungan E. coli makanan jajanan, yaitu; kebersihan orang pengolah makanan, peralatan, bahan makanan, penyajian makanan, dan sarana penjualan.

Studi pendahuluan di sekolah - sekolah dasar Desa Watuagung yang berada di Kecamatan Tambak, Kabupaten Banyumas pada Bulan Desember 2015 diketahui ; jumlah siswa sebanyak 1500 siswa, rata rata siswa tiap sekolah sebanyak 214 siswa, adanya pedagang makanan jajanan bersaus di sekitar sekolah sebanyak 30 orang, sampai saat ini belum pernah dilakukan penelitian untuk mengetahui hygiene makanan jajanan yang dijual tersebut. Berbagai perilaku yang dapat dilihat pada penjual makanan jajanan, yaitu ; pada saat melayani pembeli sambil merokok, tidak mencuci tangan terlebih dahulu dan tangan penjual juga terkadang bersentuhan langsung dengan makanan jajanan pada saat menata di tempat penjualan. Berdasarkan data di Puskesmas I Tambak tahun 2015, siswa sekolah - sekolah dasar desa Watuagung yang berobat sebanyak 48 orang, dengan diagnosa $;$ diare $=28$ siswa, muntah-muntah $=12$ siswa dan sakit perut $=6$ siswa. Setelah dilakukan penyelidikan epidemiologi/kunjungan rumah, semua penderita mengaku sering makan jajanan bersaus (cilok, siomay dan bakso tusuk). Pembinaan makanan jajanan anak sekolah masih kurang mendapat prioritas sehingga masih banyak dijumpai permasalahan hygiene dan sanitasi kantin sekolah yang kurang memenuhi syarat serta perilaku jajan anak sekolah dasar yang tidak hygienis, kesemuanya dapat memungkinkan terjadinya kontaminasi terhadap makanan jajanan di Sekolah Dasar. Berdasarkan permasalahan di atas, peneliti tertarik untuk melakukan penelitian dengan mengambil judul "Hubungan Hygiene dan Sanitasi dengan Kontaminasi Escherichia coli pada Jajanan Bersaus di Pendidikan Sekolah Dasar Se-wilayah Desa Watuagung, Kecamatan Tambak, Kabupaten Banyumas Tahun 2016”.

Tujuan dari penelitian ini adalah Mengetahui hubungan hygiene dan sanitasi dengan kontaminasi Escherichia coli pada Jajanan Bersaus di Pendidikan Sekolah Dasar Se-wilayah Desa Watuagung, Kecamatan Tambak, Kabupaten Banyumas Tahun 2016.

\section{METODE PENELITIAN}

Metode penelitian yang digunakan adalah analitik dengan pendekatan cross sectional. Obyek penelitian ini dilakukan di pendidikan Sekolah Dasar se-wilayah Desa Watuagung, Kecamatan Tambak, Kabupaten Banyumas Tahun 2016 dan Laboratorium Kesehatan Daerah Kabupaten Banyumas. Jumlah sampel sebanyak 30 penjual makanan bersaus yang ada di 
Pendidikan Sekolah Dasar se-wilayah Desa Watuagung, Kecamatan Tambak, Kabupaten Banyumas Tahun 2016 menggunakan teknik total sampling.

\section{III.HASIL PENELITIAN DAN PEMBAHASAN}

\section{Analisis Univariat}

1. Kontaminasi Escherichia coli pada jajanan bersaus

Data hasil uji laboratorium kontaminasi Escherichia coli pada jajanan bersaus pada pedagang makanan jajanan di Pendidikan Sekolah Dasar Se-wilayah Desa Watuagung, Kecamatan Tambak, Kabupaten Banyumas Tahun 2016 disajikan pada tabel berikut ini.

Tabel 1. Distribusi Frekuensi Kontaminasi Escherichia coli pada jajanan bersaus

\begin{tabular}{llcc}
\hline No & $\begin{array}{c}\text { Kontaminasi } \\
\text { Escherichia coli } \\
\text { Pada Makanan }\end{array}$ & Frekuensi & $\begin{array}{c}\text { Presentase } \\
\text { (\%) }\end{array}$ \\
\hline 1. & Tidak memenuhi \\
syarat & 15 & 50,0 \\
\hline 2. & Memenuhi syarat & 15 & 50,0 \\
\hline Jumlah & 30 & 100 \\
\hline
\end{tabular}

Tabel 1 dijadikan dasar sampel makanan yang diteliti sebanyak 30 unit dari jajanan makanan bersaus dan yang terkontaminasi E. coli sebanyak 15 makanan (50,0\%) dan yang tidak terkontaminasi sebanyak 15 makanan $(50,0)$.

2. Perilaku Hygiene Pedagang Makanan Jajanan

Data hasil observasi responden tentang perilaku hygiene pada pedagang makanan jajanan bersaus di Pendidikan Sekolah Dasar Se-wilayah Desa Watuagung, Kecamatan Tambak, Kabupaten Banyumas Tahun 2016 disajikan pada tabel berikut ini.

Tabel 2. Jumlah Skor Observasi Responden pada Check list Perilaku Hygiene Pedagang Jajanan (n = 30)

\begin{tabular}{|c|c|c|}
\hline \multirow{2}{*}{ No } & \multirow{2}{*}{ Pernyataan } & Skor \\
\hline & & $\mathbf{0}$ \\
\hline 1. & $\begin{array}{l}\text { Mencuci tangan } \\
\text { menggunakan sabun }\end{array}$ & $\begin{array}{rr}22 & 8 \\
(73,3 \%) & (26,7 \%)\end{array}$ \\
\hline 2. & $\begin{array}{l}\text { Mencuci tangan } \\
\text { menggunakan air bersih } \\
\text { yang mengalir }\end{array}$ & $\begin{array}{rr}22 & 8 \\
(73,3 \%) & (26,7 \%)\end{array}$ \\
\hline 3. & $\begin{array}{l}\text { Menutup makanan jika } \\
\text { belum ada yang membeli }\end{array}$ & $\begin{array}{rr}27 & 3 \\
(90,0 \%) & (10,0 \%) \\
\end{array}$ \\
\hline 4. & $\begin{array}{l}\text { Segera menutup makanan } \\
\text { yang disajikan setelah } \\
\text { selesai melayani pembeli }\end{array}$ & $\begin{array}{rr}26 & 4 \\
(86,7 \%) & (13,3 \%)\end{array}$ \\
\hline 5. & $\begin{array}{l}\text { Membersihkan tangan } \\
\text { menggunakan lap tangan } \\
\text { sebelum melayani pembeli }\end{array}$ & $\begin{array}{rr}26 & 4 \\
(86,7 \%) & (13,3 \%)\end{array}$ \\
\hline 6. & $\begin{array}{l}\text { Membersihkan tangan } \\
\text { menggunakan lap tangan } \\
\text { setelah melayani pembeli }\end{array}$ & $\begin{array}{rr}25 & 5 \\
(83,3 \%) & (16,7 \%)\end{array}$ \\
\hline
\end{tabular}

Perilaku hygiene pada pedagang makanan jajanan bersaus untuk mencuci tangan menggunakan sabun dan mencuci tangan menggunakan air bersih yang mengalir paling sedikit dilakukan oleh responden (73,3\%). Adapun untuk yang lainnya persentasenya di atas 80,0\%. Data tersebut selanjutnya dikategorikan untuk kegunaan analisis yang dibuat menjadi dua kategori yaitu baik dan tidak baik berdasarkan persentase jawaban sebagai berikut.

Tabel 3. Distribusi Frekuensi Hygiene Pedagang Jajanan

\begin{tabular}{|c|c|c|c|}
\hline No & $\begin{array}{c}\text { Hygiene Pedagang } \\
\text { Jajanan }\end{array}$ & Frekuensi & $\begin{array}{c}\text { Presentase } \\
(\%)\end{array}$ \\
\hline 1. & $\begin{array}{l}\text { Tidak memenuhi } \\
\text { syarat }\end{array}$ & 16 & 53,3 \\
\hline 2. & Memenuhi syarat & 14 & 46,7 \\
\hline & Jumlah & 30 & 100 \\
\hline
\end{tabular}

Tabel 3 dijadikan dasar responden yang diteliti sebanyak 30 pedagang makanan jajanan bersaus, yang perilaku hygiene pada kategori kurang baik sebanyak 16 pedagang (53,3\%) dan yang pada kategori baik sebanyak 14 pedagang (46,7\%).

3. Sanitasi Tempat Berjualan

Data hasil check list sanitasi tempat berjualan pada pedagang makanan jajanan bersaus di Sekolah Dasar Desa Watuagung, Kecamatan Tambak, Kabupaten Banyumas Tahun 2016 disajikan pada tabel berikut ini, sebagaimana ditunjukkan pada table 4 .

Tabel 4. Jumlah Skor Observasi Responden pada Check list Perilaku Hygiene Pedagang Jajanan (n $=30)$

\begin{tabular}{|c|c|c|}
\hline \multirow{2}{*}{ No } & \multirow{2}{*}{ Pernyataan } & Skor \\
\hline & & 1 \\
\hline \multirow[t]{2}{*}{1.} & Tidak dekat dengan jalan & 27 \\
\hline & raya & $(90,0 \%) \quad(10,0 \%)$ \\
\hline \multirow[t]{2}{*}{2.} & Tidak berada pada jarak & \\
\hline & $\begin{array}{l}<100 \text { m dari sumber } \\
\text { pencemaran }\end{array}$ & $(83,3 \%)(16,7 \%)$ \\
\hline \multirow[t]{2}{*}{3.} & Gerobak/tempat & 26 \\
\hline & berjualan te & $(86,7 \%)(13,3 \%)$ \\
\hline \multirow[t]{2}{*}{4.} & Langsung tertimpa sinar & $21 \quad 9$ \\
\hline & matahari & $(70,0 \%)(30,0 \%)$ \\
\hline \multirow[t]{2}{*}{5.} & Tersedia sarana cuci & $25 \quad 5$ \\
\hline & tangan $(\mathrm{k}$ & $(83,3 \%)(16,7 \%)$ \\
\hline \multirow[t]{2}{*}{6.} & Tersedia sarana cuci alat & 21 \\
\hline & (kran/el & $(70,0 \%)(30,0 \%)$ \\
\hline \multirow[t]{2}{*}{7.} & & $19 \quad 11$ \\
\hline & Tersedia rak simpan & $(63,3 \%)(36,7 \%)$ \\
\hline \multirow[t]{2}{*}{8.} & Tersedia sabun cuci & 19 \\
\hline & tangan & $(63,3 \%)(36,7 \%)$ \\
\hline \multirow[t]{2}{*}{9.} & Tersedia sabun cuci & 24 \\
\hline & peralatan & $(80,0 \%)(20,0 \%)$ \\
\hline
\end{tabular}

Tabel 4 dijadikan dasar responden yang diteliti sebanyak 30 pedagang makanan jajanan bersaus, yang sanitasi tempat berjualan dengan skor sama atau lebh kecil dari 70\%, yaitu langsung tertimpa sinar matahari, tersedia sarana cuci alat (kran/ember), tersedia rak simpan alat dan tersedia sabun cuci tangan. Data tersebut selanjutnya dikategorikan untuk kegunaan analisis 
yang dibuat menjadi dua kategori yaitu baik dan tidak baik berdasarkan persentase jawaban sebagai berikut.

Tabel 5. Distribusi Frekuensi Sanitasi Tempat Berjualan

\begin{tabular}{llcc}
\hline No & $\begin{array}{c}\text { Sanitasi Tempat } \\
\text { Berjualan }\end{array}$ & Frekuensi & $\begin{array}{c}\text { Presentase } \\
(\mathbf{\% )}\end{array}$ \\
\hline 1. & Kurang baik & 11 & 36,7 \\
\hline 2. & Baik & 19 & 63,3 \\
\hline Jumlah & 30 & 100 \\
\hline
\end{tabular}

Tabel 5 dijadikan dasar responden yang diteliti sebanyak 30 pedagang makanan jajanan bersaus, yang sanitasi tempat berjualan pada kategori kurang baik sebanyak 11 pedagang (36,7\%) dan yang pada kategori baik sebanyak 19 pedagang (63,3\%).

\section{Hasil Analisis Bivariat}

Analisis bivariat dilakukan untuk mengetahui hubungan perilaku hygiene dan sanitasi tempat berjualan dengan kontaminasi Escherichia coli pada jajanan bersaus di Sekolah Dasar Desa Watuagung, Kecamatan Tambak, Kabupaten Banyumas Tahun 2016. Hasil analisis bivariat menggunakan uji Chi Square hasilnya disajikan berikut ini.

1. Hubungan perilaku hygiene sanitasi dengan kontaminasi Escherichia coli pada jajanan bersaus

Analisis Hubungan perilaku hygiene sanitasi dengan kontaminasi Escherichia coli pada jajanan bersaus di Sekolah Dasar Desa Watuagung, Kecamatan Tambak, Kabupaten Banyumas Tahun 2016 menggunakan uji Chi Square disajikan pada tabel berikut ini.

Tabel 6. Analisis Hubungan perilaku hygiene sanitasi dengan kontaminasi Escherichia coli pada jajanan bersaus

\begin{tabular}{|c|c|c|c|c|c|}
\hline \multirow{3}{*}{$\begin{array}{l}\text { Perilaku } \\
\text { Hygiene }\end{array}$} & \multicolumn{4}{|c|}{ Kontaminasi E. coli } & \multirow{3}{*}{$\begin{array}{c}p \\
\text { Value }\end{array}$} \\
\hline & \multicolumn{2}{|c|}{$\begin{array}{c}\text { Tidak } \\
\text { memenuhi } \\
\text { syarat }\end{array}$} & \multicolumn{2}{|c|}{$\begin{array}{c}\text { Memenuhi } \\
\text { syarat }\end{array}$} & \\
\hline & $\mathbf{n}$ & $\%$ & $\mathbf{n}$ & $\%$ & \\
\hline Kurang baik & 12 & 80,0 & 3 & 20,0 & 0,003 \\
\hline$\overline{\text { Baik }}$ & 3 & 20,0 & 12 & 80,0 & \\
\hline Jumlah & 15 & 100,0 & 15 & 100,0 & \\
\hline
\end{tabular}

Tabel 6 dijadikan dasar perilaku hygiene pedagang makanan jajanan bersaus yang kurang baik sebagian besar terkontaminasi E Coli (80,0\%) dan perilaku hygiene pedagang makanan jajanan bersaus yang baik sebagian besa tidak terkontaminasi E Coli sebesar (80,0 \%). Hasil uji Chi Square diperoleh nilai $p$ value sebesar 0,003 yang lebih kecil dari $\alpha=0,05$ artinya ada hubungan yang signifikan antara perilaku hygiene sanitasi dengan kontaminasi Escherichia coli pada jajanan bersaus di Pendidikan Sekolah Dasar Sewilayah Desa Watuagung, Kecamatan Tambak, Kabupaten Banyumas Tahun 2016.

2. Hubungan sanitasi tempat berjualan dengan kontaminasi Escherichia coli pada jajanan bersaus
Analisis hubungan sanitasi tempat berjualan dengan kontaminasi Escherichia coli pada jajanan bersaus di Sekolah Dasar Desa Watuagung, Kecamatan Tambak, Kabupaten Banyumas Tahun 2016 menggunakan uji Chi Square sebagaimana ditunjukkan pada table 7 .

Tabel 7. Analisis Hubungan sanitasi tempat berjualan dengan kontaminasi Escherichia coli pada jajanan bersaus

\begin{tabular}{|c|c|c|c|c|c|}
\hline \multirow{3}{*}{$\begin{array}{c}\text { Sanitasi } \\
\text { Tempat } \\
\text { Berjualan }\end{array}$} & \multicolumn{4}{|c|}{ Kontaminasi E. coli } & \multirow{3}{*}{$\underset{\text { Value }}{p}$} \\
\hline & \multicolumn{2}{|c|}{$\begin{array}{c}\text { Tidak } \\
\text { memenuhi } \\
\text { syarat }\end{array}$} & \multicolumn{2}{|c|}{$\begin{array}{l}\text { Memenuhi } \\
\text { syarat }\end{array}$} & \\
\hline & $\mathbf{n}$ & $\%$ & $\mathbf{n}$ & $\%$ & \\
\hline Kurang baik & 9 & 81,8 & 2 & 18,2 & 0,023 \\
\hline Baik & 6 & 31,6 & 13 & 68,4 & \\
\hline Jumlah & 15 & 100,0 & 15 & 100,0 & \\
\hline
\end{tabular}

Berdasarkan pada tabel 7 diketahui bahwa sanitasi tempat berjualan dan alat yang kurang baik sebagian besar tidak terkontaminasi $E$ Coli sebesar $(81,8 \%)$ dan sanitasi tempat berjualan dan alat yang baik sebagian besar tidak terkontaminasi E Coli sebesar (68,4\%). Hasil uji Chi Square diperoleh nilai $p$ value sebesar 0,023 yang lebih kecil dari $\alpha=0,05$ artinya ada hubungan yang signifikan antara sanitasi tempat berjualan dengan kontaminasi Escherichia coli pada jajanan bersaus di Pendidikan Sekolah Dasar Se-wilayah Desa Watuagung, Kecamatan Tambak, Kabupaten Banyumas Tahun 2016.

\section{IV.KESIMPULAN DAN SARAN}

\section{Kesimpulan}

Kesimpulan penelitian sesuai dengan hasil penelitian dan pembahasan sebagai berikut:

a. Makanan jajanan yang berasal dari 30 pedagang, yang terjadi kontaminasi E. coli sebanyak 15 makanan (50,0\%) dan yang tidak terjadi kontaminasi sebanyak 15 makanan (50,0\%).

b. Perilaku Hygiene pada kategori kurang baik sebanyak 16 pedagang (53,3\%) dan yang pada kategori baik sebanyak 14 pedagang (46,7\%).

c. Sanitasi tempat berjualan perilaku hygiene pada kategori kurang baik sebanyak 11 pedagang (36,7\%) dan yang pada kategori baik sebanyak 19 pedagang (63,3\%).

d. Ada hubungan yang signifikan antara perilaku hygiene sanitasi dengan kontaminasi Escherichia coli pada jajanan bersaus di Pendidikan Sekolah Dasar Se-wilayah Desa Watuagung, Kecamatan Tambak, Kabupaten Banyumas Tahun 2016 (p value $=0,003$ ).

e. Ada hubungan yang signifikan antara sanitasi tempat berjualan dengan kontaminasi Escherichia coli pada jajanan bersaus di Pendidikan Sekolah Dasar Se-wilayah Desa Watuagung, Kecamatan Tambak, Kabupaten Banyumas Tahun 2016 (p value $=0,023)$. 


\section{Saran}

Saran-saran yang dapat diberikan sesuai kesimpulan penelitian yaitu:

a. Bagi Institusi

1. Bagi institusi pendidikan, hasil penelitian ini perlu dipublikasikan agar dapat dijadikan referensi ilmiah bagi peneliti.

2. Bagi institusi kesehatan, hasil penelitian ini dapat dijadikan bahan pertimbangan dalam upaya melakukan pengawasan makanan jajanan yang dijajakan di sekolah dasar.

b. Bagi Pemerintah

Pemerintah lebih memperhatikan upaya melindungi kesehatan masyarakat, khususnya pada pelajar dengan melakukan pengawasan terhadap makanan jananan para pedagang di sekolah.

c. Bagi Peneliti

Penelitian ini perlu dikembangkan lebih lanjut dengan meneliti faktor lain yang dapat mempengaruhi kontaminasi E. coli dengan meneliti praktek pengolahan makanan di rumah pedagang.

d. Bagi Para Pedagang

1. Para pedagang hendaknya membiasakan mencuci tangan menggunakan sabun dan mencuci tangan menggunakan air bersih yang mengalir.

2. Pedagang tidak berjualan di tempat yang langsung tertimpa sinar matahari. Selain itu, pedagang juga perlu menyediakan sarana cuci alat (kran/ember), rak simpan alat dan sabun cuci tangan.

\section{DAFTAR PUSTAKA}

Arikunto, S. (2006). Prosedur penelitian suatu pendekatan praktek. Jakarta: PT. Rineka Cipta

Arisman, (2009). Buku Ajar Ilmu Gizi Keracunan Makanan. Jakarta: EGC

Azwar, S. (2006). Pengantar Administrasi Kesehatan. Jakarta : Binarupa Aksara.

BPOM, (2005). Peraturan Kepala Badan Pengawasan Obat dan Makanan Republik Indonesia Nomor HK 00.05.41.1384 tentang Kriteria dan Tata Laksana Pendaftaran Obat Tradisional, Obat Herbal Terstandar dan Fitofarmaka. Jakarta : Kepala BPOM.

BPOM, (2010). Upaya BPOM Dalam Menghadapi Tantangan Keamanan Pangan Jajanan Anak Sekolah, Jakarta : Penerbit BPOM.

Budiarto, Eko. (2004). Metode Penelitian. Jakarta: EGC.
Dahlan, Sopiyudin M, (2008). Statistik Untuk Kedokteran dan Kesehatan. Jakarta: Salemba.

Depkes RI, (2004). Hygiene dan Sanitasi Makanan dan Minuman. Jakarta. Dirjen PPM dan PL.

Depkes RI, (2010). Hygiene dan Sanitasi Makanan dan Minuman. Jakarta. Dirjen PPM dan PL.

Desmaslima (2009). Pemeriksaan E. coli pada Usapan Peralatan Makanan yang Digunakan oleh Pedagang Makanan di Pasar Petisah Medan Tahun 2009

Fitka Romanda, (2012). Hubungan Personal Hygiene Dengan Keberadaan Escherichia Coli Pada Makanan Di Tempat Pengolahan Makanan (TPM) Buffer Area Bandara Adi Soemarmo Surakarta.

http://eprints.ums.ac.id/42231/1/naskah\%20pu blikasi.pdf

Hambali, E., A. Suryani, dan M. Ihsanur., (2006). Membuat Saus Cabai dan Tomat. Jakarta. Penebar Swadaya.

Hartono, Andry. (2006). Terapi Gizi dan Diet Rumah Sakit. Jakarta: EGC.

Judarwanto, Widodo. (2010), Enterobacter Sakazakii, Bakteri Pencemar Susu. RS Bunda Jakarta \& Picky Eaters Clinic. http://medicastore.com.

Kemenkes RI, (2012). Pedoman Gizi Seimbang. Jakarta: Kemenkes RI.

Keputusan Menteri Kesehatan RI No. 715 Tahun tentang Persyaratan Higiene Sanitasi Jasaboga

Mariana (2006). Perilaku Konsumsi Sarapan Pagi dan Makanan Jajanan Serta Status Gizi Siswa SLTP Negeri 17 dan SLTP Perguruan Budi Satrya di Kecamatan Medan Tembung Tahun 2006. Skripsi Gizi Kesehatan Masyarakat, FKM USU

Mudey, A. B., Kesharwani, N., Mudey, G A., Goyal, R. C., Dawale, A. K., Wagh V. (2010). Health Status and Personal Hygiene among Food Handlers Working at Food Establishment around a Rural Teaching Hospital in Wardha District of Maharashtra, India. Global Journal of Health Science. Vol. 2, No.

Musaddad, D. dan N. Hartuti, (2003). Produk Olahan Tomat. Jakarta. Penebar Swadaya.

Naria, Evi.. (2005).Higiene Sanitasi Makanan dan Minuman Jajanan Di Kompleks. Skripsi. USU, Medan, 
Nely Zufa, (2011). Hubungan Higiene Personal Pedagang dan Sanitasi Makanan dengan Keberadaan Escherichia coli pada Nasi Rames di Pasar Johar Kota Semarang Tahun 2011. http://lib.unnes.ac.id/8119/1/8600.pdf

Notoatmodjo, S. (2005). Metodologi Penelitian Kesehatan. Jakarta : Rineka Cipta

Nursalam, (2012). Manajemen Keperawatan: Aplikasi dalam Praktik Keperawatan Profesional. Jakarta: Salemba Medika.

Rachmawati, (2013) Praktik Higiene Personal dan Keberadaan Bakteri Escherichia coli pada Tangan Penjamah Makanan (Studi pada Pedagang Kaki Lima di Jalan Kalimantan Kecamatan Sumbersari Kabupaten Jember). http://repository.unej.ac.id/handle/123456789/ 72293

Riris, Lindiawati Puspitasari (2013) Kualitas Jajanan Siswa di Sekolah Dasar. Jurnal Al-Azhar Indonesia Seri Sains Dan Teknologi, Vol. 2, No.1, Maret 2013

SNI 01-3546-2004 Saus tomat

Sofiana, Erna. (2012) Hubungan Higiene dan Sanitasi dengan Kontaminasi E. coli pada Jajanan di Sekolah Dasar Kecamatan Tapos
Depok. Skripsi Kesehatan Masyarakat, FKM UI

Suprapti, L., (2000). Membuat Saus Tomat. Jakarta. Trubus Agisarana,

Sutardi dan Kapti, R. K., (1994). Kajian Penggunaan Pepaya dan Ubi jalar Sebagai Bahan Campuran Saus Tomat. Jurusan Teknologi Pengolahan Hasil Pertanian, Fakultas Teknologi Pertanian, Universitas Gadjah Mada, Yogyakarta.

Tarwotjo C.S., (1998). Dasar-Dasar Gizi Kuliner. Jakarta.Grasindo.

Wijaya, J. I. (2013). Formulasi Sediaan Gel Hand Sanitizer Dengan Bahan Aktif Triklosan 1,5\% dan 2\%. Jurnal Ilmiah Mahasiswa Universitas Surabaya. Vol 2, No 1

Wulan Anggorowati. (2014). Hubungan Higiene Sanitasi Dan Perilaku Penjamah Makanan Dengan Kontaminasi Escherichia Coli Pada Jajanan Di Pasar Tradisional Sekitar Pusat Kota Klaten. http://eprints.undip.ac.id/43298/1/4827.pdf

Yunaenah, (2009). Kontaminasi Escherichia coli Pada Makanan Jajanan Di Kantin Sekolah Dasar Wilayah Jakarta Pusat Tahun 2009. Tesis. FKM UI. 